\title{
Learning Indonesian History during the Western Nation Period Based on Local History
}

\author{
Rosmaida Sinaga ${ }^{1}$, Lister Eva Simangunsong ${ }^{2}$, Syarifah $^{3}$ \\ \{rosmaidasinaga@unimed.ac.id ${ }^{1}$, listeresimangunsong@unimed.ac.id ${ }^{2}$. syarifah@unimed.ac.id ${ }^{3}$ \} \\ Department of History, Universitas Negeri Medan, North Sumatera, Indonesia ${ }^{1,2,3}$
}

\begin{abstract}
This study aims to determine the reasons for the implementation of the learning Indonesian History during the Western Nations Period based on Local History and the development of Indonesian History teaching materials with the local content being the people of Medan, North Sumatra, during the Colonial Period by Western Nations. The research method used herein is historical research consisting of four stages, namely heuristics, source criticism, interpretation/analysis, and historiography. Based on research results it is known that Indonesian History Learning of the Western Nation Period based on Local History must be implemented because the master book for Indonesian History during the Western Nations Period is very minimal in discussing Dutch colonialism and its impact on the people of Medan City, North Sumatra. One of the impacts of the presence of Western nations is the creation of multiculturalism in the Medan society of North Sumatra. With this understanding, it is hoped that the people of Medan in North Sumatra will be more tolerant, thereby maintaining national integration.
\end{abstract}

Keywords: Indonesian History Learning, Local History

\section{Introduction}

The course of Indonesian History during the Western Nation Period is a compulsory subject for students of the Department of History Education. The course examines the struggle of the Indonesian people against the colonization of Western nations in Indonesia. In learning, the course textbooks are used both those published by the government and those written by historians. Textbooks that are used as references for these subjects generally only describe the material in a national context, so it is very minimal to discuss the resistance of the people of North Sumatra to colonialism. The textbooks do not even discuss the impact of colonialism on the people of North Sumatra, especially regarding the creation of multiculturalism in the people of Medan, North Sumatra.

Therefore, learning materials on Indonesian History of the Western Nation Period should also be filled with local content. This is intended to make history teaching more contextual so that students better understand the subject matter of Indonesian History during the Western Nations Period. Therefore, the authors took an interest in studying the history of Indonesia during the Western Nations Period based on Local History using historical research methods. In the heuristic stage, the authors traced historical sources to the North Sumatra Province library, Medan State University library and the Plantation Museum and observed locations that serve proofs of the multiculturalism in Medan City. After the historical sources have been obtained, the authors verified the source to find historical facts, which were subsequently 
interpreted and analyzed. Then the historical facts are arranged in writing history (historiography).

\section{Method}

This research is used a history method with 4 stages which are heuristic, verification or sources criticism, interpretation, and historiographic. The heuristic stage is done by reading books related to the topic. The researcher found the book in several places such as Universitas Negeri Medan Digital Library, National Archive in Jakarta, and also Province Library. The research also used observation in several fields in Medan. The verification of data by comparing the data from the books and museum of Planting North Sumatera. The researcher did interview the descendants of plantation workers. After finishing the second stage, the researcher continued to interpret historical facts. The final stage was writing the historical facts that already interpreted into a history.

\section{Result and discussion}

In the Department of History Education, there are volumes of textbooks such as Indonesian National History which consist of 6 volumes; Indonesian textbooks in the History Flow (IDAS) consisting of 8 volumes. One of the courses in the Department of History Education in the History of Indonesia during the Western Nations Period. During the course, students used several textbooks as a mandatory-references. The textbooks used in the lectures on Indonesian History of the Western Nation Period are as follows: (1) Sejarah Nasional Indonesia Jilid IV (National History of Indonesia, Vol. IV), (2) Indonesia Dalam Arus Sejarah Jilid V (Indonesia in the Course of History, Vol. V), (3) Pengantar Sejarah Indonesia Baru Jilid I dan II (New Introduction to Indonesian History, Vol. I and II), (4) Sejarah Indonesia Abad XIX Awal Abad XX (Indonesian History of the 19th and Early 20th Century), and (5) Sejarah Indonesia Modern 1200-2004 (Modern Indonesian History 1200-2004).

One of the mandatory textbooks in the course of Indonesian History during the Western Nations Period is the National History of Indonesia Volume IV, 4th Edition Printing Edition, published in 2010. The textbook has little information regarding the resistance of the people of North Sumatra to colonialism and exploitation by Western nations. This is evident from the small number of pages in the textbook discussing the resistance of the people of North Sumatra, namely 260-278. In addition to the minimal number of pages, the textbook only describes the War in the Batak Land, specifically the resistance of Sisingamangaraja XII against the Dutch colonial government.

In the textbook Indonesian in the course of History Volume V, there were also very few descriptions of the condition of the people in North Sumatra during the Dutch Colonialism. The textbook was found to have additional pages discussing the North Sumatra region. The topics of discussion regarding North Sumatra are the Turbulent period of North Sumatra (1872-1904) and Sisingamangaraja XII's Resistance in the Batak Land (1878-1904).

In the textbook New Introduction to the History of Indonesia Volume II there is no discussion about the people of North Sumatra during the Dutch colonial rule. Likewise, the textbooks Modern Indonesian History and Indonesian History of the 19th and Early 20th Century did not discuss the condition of North Sumatran people during the Dutch colonial 
rule. Thus, the compilation of teaching materials on Indonesian history during the western nations period based on local history is important to fill in the holes in Indonesian national history.

In 1870 the conservative colonial politics of the Dutch Colonial Government was officially changed to liberal colonial politics. The change of colonial politics was motivated by the condition of politics in the Netherlands which was controlled by liberals who occupied the majority of their parliament. The Dutch Parliament at that time did not approve of the forced cultivation system that was implemented by the Dutch in Java. The Dutch Parliament which was dominated by liberals had intended to help the Javanese population and increase the economic benefits of its colony in the Dutch East Indies. To achieve this goal, the Dutch Parliament allowed the establishment of several private companies. The liberals at that time did not approve the forced cultivation system because the colonial government was considered arbitrarily taking over people's land. Therefore, the Agrarian Law was issued in 1870 aimed at securing the ownership of land by the farmers. The contents of the Agrarian Law of 1870 were as follows: (1) the Governor-General of the VOC does not allow the sale of governmentowned land. However, the land can be leased for a maximum of approximately 75 years, (2) land owned by the government includes, among others, unopened forest, those located outside the village area and its inhabitants and customary land, and (3) land owned by residents, including all fields, and fields owned directly by villagers. Such land may be rented by foreign investors for around 5 years.

The liberal economic system was in effect from 1870 to 1900 . The Dutch Colonial Government provided opportunities for private capital to open large plantations in Java and outside Java. This opportunity was used by the Dutch and another European private sector to establish coffee, tea, sugar, quinine and tobacco plantations in Deli, East Sumatra.

Europeans and other foreigners can lease government land, ie those that have not been cultivated by the population. Agricultural industry entrepreneurs obtained business rights (erfpacht) for 75 years. The parcels of land should not exceed 500 shoulders (355 ha). An individual may not rent more than one parcel. Europeans who cannot afford to rent land parcels of an area must not exceed 25 shoulders for a maximum period of 25 years. Likewise, the capitalists can still rent rice fields from the Indonesian people for a maximum period of 25 years [1]. The purpose of the Agrarian Law issued by the Dutch colonial government in 1870 is as follows: (1) protecting farmers' property rights over their land from foreign rulers and financiers, (2) providing opportunities for foreign investors to lease land from Indonesian residents, such as from England, Belgium, the United States, Japan, and China, etc., and (3) opening vacancies for residents to become plantation laborers.

With the adoption of the Agrarian Law, the people are legally free to lease their labor and land to private plantations. Land leases are determined based on the agreement of both parties freely. The adoption of the Agrarian Law encouraged the entry of European plantation industries into Indonesia. One of the areas targeted by the European plantation business industry is East Sumatra. The Deli area is the first plantation industrial area in East Sumatra. The foundation of the Deli tobacco estate was built after Sultan Deli Mahmud Perkasa Alam approved the entry of foreign capital in 1862. The granting of such permit has opened doors for the Dutch capitalists to open a tobacco plantation in Deli. In 1863, Jacob Nienhuys arrived at Deli with a mission to establish a tobacco plantation in Deli. At that time, the Deli area was not yet known by the Dutch people. Jacob Nienhuys was the first person to open a tobacco plantation in Deli in 1865. Jacob Nienhuys' tobacco plantations continued to grow that in 1869 he founded a plantation company called Deli Maatschappij [2]. 
The opening of Deli tobacco plantations requires workers (laborers) to be employed on the plantations. At the beginning of the opening of a plantation in Deli, employers experienced difficulties in finding workers. The search for labor is more difficult than the search for plantation land. Unlike the case with plantation companies in Java, the expansion of their land developed forward due to the labor available from the surrounding villages. Plantation companies on the east coast of Sumatra initially imported hundreds of thousands of Chinese and Javanese Chinese workers, who were housed and fed in plantation barracks and bound by slave status [3].

Indigenous people who inhabit the Deli area are less interested in becoming laborers on plantations. Sultan Deli can provide the land but not labor because indigenous people (Bataks and Malays) cannot be persuaded nor forced by local or foreign officials to be employed on plantations. Therefore, plantation entrepreneurs are forced to look for workers from outside the Deli area, namely first in Malaya, Singapore, and China, then in poor villages in Central Java to get labor, and in Europe to find management staff. Recruitment of workers is done through brokers until a time when plantation entrepreneurs began to organize their convoys directly from China [3]. At the beginning of the plantation opening, the workers were brought in from Singapore. The workers who came from Singapore were Chinese. After Deli Maatschappij was formed by Jacob Nienhuys, there was an addition of 800 Chinese workers to increase production in the plantation [2].

The opening of tobacco plantations on the east coast of Sumatra in 1863 led to the largescale immigration of Chinese laborers. Before World War I, the Chinese were the only source of labor on the plantation. Initially, the plantation owners got Chinese laborers in Singapore, Pinang or even Deli themselves, from brokers in the Malacca Strait region. Since 1888, Deli plantation owners have brought about 7,000 workers a year from China, mainly from the Guangzhou area, so that in 1930 there were nearly half a million Chinese workers employed at Deli plantations. In 1930, the Dutch colonial government required plantation owners to pay an immigration tax of 100 guilders for each laborer brought in from China. The tax was considered to be too high, so the plantation entrepreneurs switched to employing workers from Java. Even though the plantation owners switched to employing Javanese workers, this did not mean that workers from China immediately left Sumatra. Some of them settled in urban areas and developed trade and business activities. The Dutch colonial government supported the activities of the Chinese and made them intermediaries between Europeans and the natives. Some of the Chinese laborers who were laid off from plantations spread to the highlands north of Lake Toba and became vegetable traders or farmers [4].

Increased labor immigration is in line with the expansion of plantation land in Deli. The first harvest from the tobacco plantations of Jacob Nienhuys was sent to the Netherlands in early 1864 . The tobacco that was sent was judged to have special qualities, so Jacob Nienhuys signed a land concession with the Deli sultan in 1865. After signing the concession, in 1865 also two planters Switzerland and a Prussia planter arrived at Deli to open a plantation. At that time they were engaged in tobacco, nutmeg and coconut plantations. In 1967, Jacob Nienhuys obtained a new concession between Percut River and Deli. In 1868, Deli had already established six large plantations that produced more than 200 tons of tobacco. A large amount of Deli tobacco production pushed Jacob Nienhuys to establish Deli Maatschappij in 1869. At the time Deli Maatschappij was founded, the company already owned 7,000 hectares of land which was used as a tobacco cultivation site. In 1870 Deli Maatschappij employed 1,200 Chinese labors out of a total of 3,000 labors working in the Deli Sultanate region. Increased labor requirements in Deli Maatschappij strengthen relations with the Malay Peninsula, specifically Pinang and Singapore. The King people were brought in from Pinang to do 
drainage work. Pinang also brought Chinese carpenters to build two wooden houses, namely one large house for planters and one smaller house for employees from Europe. Then Boyang people recruited from Singapore set up other buildings, thatched huts, and huts. Residents and the Banjar people were employed to build wards used as a place to dry tobacco [4].

The development of plantations also attracted Indians who were grouped into 4 groups namely Keling, Bengali, Chetti, and Bombay. Another group of migrants who became laborers at the Deli plantation were the Banjar people from Kalimantan who worked as construction workers who set up tobacco drying wards and cleared forests before forming colonies of rice farmers along the coast. The Boyang from Bawean Island between Java and Borneo were recruited in Singapore to be employed for the construction of workers' dwellings and thatched huts. The Siamese work to clear the forest, open roads and build buildings. The opening of European plantations in East Sumatra also attracted migrants from Minangkabau who later became small traders or craftsmen. Before World War II, Peninsular Malays also migrated to the East Coast on the grounds of improving their economy. There were also Acehnese who migrated to Deli and became barge drivers in Belawan. In 1870 residents from the north, east and south of Lake Toba also migrated to hamlets near plantations. The reason for their migration was because of the small income as farmers in the highlands and the charm of mountain slope life near the plantations which were considered better at that time. In the 1870s, many Raya residents in the northeast of Lake Toba who was then under the authority of Mr. Rondahaim left riot-stricken areas towards the lowlands and mountain slopes of Coal and Dolok. In 1929, more than a thousand Toba Bataks settled in the lowlands of Deli Serdang, including in Medan [4].

Demand for labor increased with the development of plantations in Deli. As a result, the price of laborers coming from the Malay Peninsula became increasingly expensive, so plantation owners started looking for workers in India and China. Their search for laborers also faced obstacles because the British imposed rules that restricted workers out of India, along with the sensitivity of Chinese people to money. Therefore, the plantation owners began to look for other alternatives, namely workers from Java that were available at any time. Although workers from Java were always available, many plantation owners at that time refused workers from Java, especially laborers who were employed to treat tobacco [5].

Since 1875 there has been a phenomenon in the recruitment of local workers by plantations in Deli. In 1873 Deli Maatschappij employed around 350 people to clear the forest for tobacco plantations, build huts for workers, care for banana and nutmeg plantations, and transport goods by canoe. In 1880 people from the mountains arrived at Deli because they were attracted by the European dollars. They offered the power to build huts and wards. They worked in groups under the leadership of their tribe and refused to mingle with the Chinese or Malay workers. In 1883 thousands of people came down from the mountains to work on plantations. The transfer was not only carried out by ordinary people but also by people from the interior who tried to accumulate wealth to increase their influence in their home regions. When they migrated, respected figures from the interior brought their people to negotiate with the Tuan, the plantation manager.

After procuring a job, they built a separate house occupied by 50 to 60 men. In general, they were given a small field to grow rice, with the yields being sold to plantations. When the work was done and they felt they had enough money, they returned to the highlands and were replaced by others. In 1883, an estimated quarter to one-third of the male population living on the northeast bank of Lake Toba left for Deli to work on plantations. These nomads are classified in the category of laborers, foremen, and heads of plantations. The work of the foreman held a certain prestige because they usually had a familial relationship with the king, 
while the head of the plantation was chosen from among them with the tasks of recruiting, carrying out negotiations with the planters and responsible for the smooth operations of the plantation. The head of the plantation received wages of between 5 and 10\% of the labor payment and when they returned, the king took the majority of the rest. Inland people gained a good reputation as forest clearers and constructors. They were also assigned to arrest escaped workers. If they succeeded in capturing workers who have fled, they were paid several guilders per person. Since the mid-1920s, many Malays worked as day laborers on tobacco plantations, especially women and children. Malays were generally employed to pick up caterpillars and sort tobacco [4].

The presence of workers from outside Sumatra (China, India, and Java) formed a heterogeneous pattern of settlement. Besides, the color of the skin and ethnic origin often determined the work position of the workers on the plantation. The division of labor was based on ethnicity/skin color. Javanese were employed as land diggers and road makers on plantations. The Baewan were considered suitable for constructing drying wards and porters housing. Keling people were deemed suitable for earth digging work. Banjarese and Siamese were assigned to build draining barns. Malays were employed as coachmen. Batak people worked as contract workers in lodging construction and deforestation, while the Chinese became the main workers (Breman, 1995: 98-99). The division of labor was intended by the plantation owner for work efficiency and optimization of plantation production. The plantation owners also believed that ethnic heterogeneity in the same task must be reduced because it often triggered fights between fellow workers of different ethnicities/nationalities. The recruitment of workers from Java was regulated by an institution called Vrij Emigratie Deli Avros (VEDA). The VEDA Institute was tasked with finding workers from Java to be employed in Deli plantations and other similar plantations in East Sumatra. In 1874, VEDA had brought 316 workers from Java to plantations in Deli [6].

In 1875 Deli Maatschappij brought in suitable workers to be employed on plantations, namely Javanese from Bagelan. In general, the level of satisfaction of plantation owners towards Javanese workers at that time was very low, because they were considered very lazy and unsuitable for tobacco plantation work. Therefore, these workers are assigned to menial work such as land clearing and road construction. In 1911 more 50,000 contract workers were brought in from Central Java. The reason for the flood of Javanese to Deli was due to the decline in welfare in their home regions. In 1912, on the Deli estate, there were 100,000 more men than women, and of 100,000 ethnic Chinese, nearly 93,000 were men. The comparison between male workers and female workers is very lame. As a result, women became the focal point of conflict between Chinese and Javanese and were the reason for the ferocious attacks by Asian workers on European managers. Young female porters who were almost all Javanese were forced to prostitute themselves. The female workers served the sexual needs and general household needs of male workers and managers. In 1894 the salary of women workers was only half of their male counterparts and was not enough for daily food needs. The low wage for women workers was the cause of widespread prostitution and venereal disease among plantation residents at that time. The female workers were also used as bait to lure male workers to Deli and as solace to retain them there [3].

Before the opening of a tobacco plantation in Deli, there were already people living in the Deli area. The coastal population in the East Sumatra region was called Malay. The majority of Malays on the east coast of Sumatra descended from Minangkabau migrants. Others who migrated to the area were Chinese. Chinese migration began during the construction of Singapore in 1819. In the 1840s people from the south of Tapanuli migrated to the east coast of Sumatra. The activities of migrants from the south of Tapanuli in Deli are related to their 
religion: Islam. Others who migrated to the region were depicted in the Hikayat Deli, which states that an Indian came to Deli in the 17 th century. Besides, there were also other migrants such as sailors from Malabar and Coromandel stranded on the east coast of Sumatra, Aceh, Java, Borneo, Sulawesi, Trengganu, port cities in the Malay Peninsula, Riau, Lingga and others [4]. Not many migrants came to the east coast of Sumatra before the opening of Deli tobacco plantations as told in the Hikayat Deli. From among the migrants coming to the area were stranded sailors. This means that the number of stranded sailors was certainly not as much as the workforce deliberately brought in to become Deli tobacco plantation workers.

The opening of plantations in East Sumatra created multicultural plantation communities. The presence of plantation workers from outside Deli caused the population of the region to be very heterogeneous. Residents living in the Deli area consisted of various ethnic groups/races. Besides, the presence of plantation workers also played a role in increasing the population in the region. The composition of labor based on ethnicity working in East Sumatra plantations can be seen in the following Table 1 below.

Table 1. Composition of Ethnicity of Plantation Labor in East Sumatra

\begin{tabular}{lcccccc}
\hline \multirow{2}{*}{ Ethnicity } & \multicolumn{5}{c}{ Year (s) } \\
\cline { 2 - 7 } Chinese & 1874 & 1884 & 1890 & 1900 & 1916 & 1926 \\
Javanese & 4,476 & 21,136 & 53,806 & 58,516 & 43,689 & 27,133 \\
Indian & 316 & 1,771 & 14,847 & 25,224 & 150,329 & 194,189 \\
$\quad$ Total & 459 & 1,528 & 2,460 & 3,270 & - & - \\
\hline
\end{tabular}

Source: Reid, 2010: 220.

Based on the data in the table it can be seen that up to 1900, there were still more Chinese workers employed in the East Sumatra plantations compared to the Javanese. However, since 1916 the number of Chinese laborers employed on East Sumatra plantations began to decrease. The declining number of Chinese laborers employed on plantations is related to the high taxation imposed by the Dutch Colonial Government to plantation owners who brought in Chinese laborers from outside Deli, so that plantation owner sought to find solutions by bringing in more labor from Java. Unlike the Indian workers, the British colonial government implemented a policy restricting workers' migration from India, making it difficult for Indian workers to leave India to be employed as laborers.

An increase in the number of Javanese workers employed on East Sumatra plantations was due to the growing trust of plantation owners in workers from Java. Besides, Javanese labor prices were cheaper than Chinese laborers, both in terms of wages and transportation funds from their home to Deli. In such conditions, Javanese workers became the best choice as plantation laborers. Many Javanese workers were willing to be sent to East Sumatra to be employed on plantations. The willingness of these Javanese workers was related to the decreasing welfare of the Javanese population (Stoler, 2005: 48). The plantation community consists of Europeans, Chinese, Indians, Javanese, and other natives. The population census in 1930 illustrates the multiculturalism of Afdeeling Deli Serdang inhabitants. The Afdeeling Deli-Serdang population in 1930 was as follows in Table 2 below.

Table 2. The composition of the population on the afdeeling Deli-Serdang, 1930 


\begin{tabular}{cccccc}
\hline Area & $\begin{array}{c}\text { Indigenous } \\
\text { Population }\end{array}$ & $\begin{array}{c}\text { European and } \\
\text { the likes }\end{array}$ & Chinese & Other Asians & Total \\
\hline Afd. Deli Serdang & 431,599 & 6,307 & 88,740 & 9,357 & 536,603 \\
\hline
\end{tabular}

Source: Perret, 2010: 41

From these data, it is known that the indigenous population in Afdeeling Deli-Serdang made up $80 \%$ of the entire population. The second largest was Chinese, namely $17 \%$. In third place were other Asians, 2\%. The population from Nusantara in Afdeeling Deli-Serdang in 1930 was as follows on the Tabel 3 below.

Table 3. Indonesian Population in Afdeeling Deli-Serdang in 1930

\begin{tabular}{cc}
\hline Tribe & Afdeling. Deli Serdang \\
\hline Malay & 61,953 \\
Batak & 81,012 \\
Aceh & 1,167 \\
Minangkabau & 11,856 \\
Other parts of Sumatra & 1,037 \\
Banjar & 14,443 \\
Outside Sumatra and Java & 797 \\
Java & 231,044 \\
Sunda & 17,516 \\
Madura & 822 \\
Batavia & 3,899 \\
Banten & 3,689 \\
Others & 2,308 \\
Total & 431,599 \\
\hline
\end{tabular}

Source: Perret, 2010: 42

Based on these data it can be seen that the number of Javanese population in Afdeeling Deli-Serdang amounted to 54\%. The second-largest population in the area was those of Batak Tribe, amounting to $19 \%$. The third-largest population is occupied by Malays, amounting to 14\%. In 1930 the Batak tribe in Afdeeling Deli Serdang numbered 81,012 people. The Batak tribe consists of several Batak sub-tribes. Details of the Batak sub-tribes in Afdeelling Deli Serdang are as follows in Table 4 below.

Table 4. Batak Population in Deli Serdang Afdeeling 1930 


\begin{tabular}{cc}
\hline Batak & Afdeling deli serdang \\
\hline Batak (non-descript) & 3,608 \\
Angkola & 1,148 \\
Karo & 37,341 \\
Mandailing & 20,198 \\
Padang Lawas & 23 \\
Pakpak & 55 \\
Simalungun & 16,167 \\
Toba & 2,472 \\
Total & 81,012 \\
\hline
\end{tabular}

Source: Perret, 2010: 42

Based on these data it is known that the highest percentage of Batak in Afdeling DeliSerdang was Karo Batak, which made up $46 \%$ of the tribe's population. The second highest was Mandailing Batak at 25\%, while the third-highest was the Simalungun Batak at $20 \%$. Based on the results of the 1930 census, it was found that before Indonesian independence in the Deli region (now Medan City), ethnic diversity was already present in that area. The diversity of the Medan City community, North Sumatra, with different social life backgrounds has various complex dimensions. It cannot be denied that the problem of community diversity is potentially vulnerable to social conflict. However, it is also possible that the diversity of society can potentially strengthen the integration, if all the components of the society can accept community differences as a gift from God Almighty.

\section{Conclusion}

Indonesian National History books which are used as master books in the History Education Department are very minimal in discussing the condition of the people of Medan City in particular and the people of North Sumatra in particular. Therefore, the implementation of local history-based learning is very important in learning Indonesian History during the Western Nations Period. The Dutch colonial government's policy in North Sumatra which played a role in creating a multicultural society in Medan was the 1870 Agrarian Law in the Dutch East Indies.

The adoption of the 1870 Agrarian Law provided broad opportunities for capital owners in the Netherlands in particular and Europe, in general, to invest in the Dutch East Indie, by opening plantations in Deli in particular and in East Sumatra in general. The opening of plantations in the region led to an increase in the need for plantation workers. As such, the plantation owners brought laborers/workers from outside the region, namely Chinese and Indian and Javanese, to be employed on the plantation. The impact of the Dutch colonial government's policy in North Sumatra in general and in Medan City in particular as the capital of North Sumatra Province was the creation of a multicultural society.

\section{References}

[1] Daliman, Sejarah Indonesia Abad XIX Awal Abad XX: Sistem Polotik Kolonial dan Administrasi Pemerintahan Hindia Belanda. Yogyakarta: Ombak, 2012.

[2] M. Said, "Suatu Zaman Gelap di Deli: Koeli Kontrak Tempo Doeloe Dengan Derita dan 
Kemarahannya," PT. Harian Waspada Medan, Medan, 1990.

[3] A. L. Stoler, Kapitalisme dan Konfrontasi di Sabuk Perkebunan Sumatera. Yogyakarta: Karsa, 2005.

[4] D. Perret, Kolonialisme dan Etnisitas: Batak dan Melayu di Sumatera Timur. Jakarta: Gramedia.

[5] A. Reid, Sumatera Tempo Doeloe: Dari Marco Polo Sampai Tan Malaka. Depok: Komunitas Bambu, 2010.

[6] U. Pelly, Sejarah Sosial: Daerah Sumatera Utara Kota Madya Medan. Jakarta: Depdikbud, 1984. 